\title{
Analysis of College English Teaching Model Based on Network Automation Transformation
}

\author{
Xiaoli Bao ${ }^{1, *}$ \\ ${ }^{1}$ School of Foreign Languages, Inner Mongolia University for Nationalities, Tongliao, Inner Mongolia, China
}

\begin{abstract}
English education in colleges and universities has always been limited to the conventional teaching mode by multiple restrictions such as lecture system, teaching objectives and students' quality for years. Based on the hot topic of automation transformation, this paper will analyze the problems faced by English teaching in colleges and universities from the perspective of the most popular Internet + education, collect and organize relevant data, and then put forward relevant suggestions for the development of English teaching in colleges and universities, and put forward the prospect of its development in the future, with the aim of promoting the transformation of college English teaching mode in order to improve the teaching quality of English classroom.
\end{abstract}

\section{Introduction}

Under the background of "Internet+" era, the traditional English teaching methods and teaching modes are bound to be impacted and changed. At present, English teaching faces many general problems, such as insufficient teaching resources, imbalanced teacherstudent ratio, and weak teachers, all of which are in urgent need of change. In addition, characteristic problems are also emerging, focusing on the lack of comprehensive language skills, lack of independent learning ability, old English learning habits, and poor expression of academic English; the lack of professional skills or abilities of English teachers and their single knowledge structure; and the need to cultivate complex talents cannot be met. In the new era of "Internet+", new learning methods have emerged, and online learning has further challenged the single, traditional English teaching method. With the deep integration of online and offline, teachers should also improve their teaching ability, their role and role in the classroom has changed, and their educational philosophy should be constantly innovated.

\section{The Dilemma Faced by College English Teaching}

\subsection{Insufficient teaching resources}

Teaching resources mainly include English learning materials, media, English teaching infrastructure equipment, application environment, reference literature and materials, etc. China's social progress, economic growth, and the state's investment in funds and facilities for education and teaching are increasing year by year, which cannot be compared with the previous ones, but facing the difficulties of the new period, that is, the growing team of teachers and students and the large number of demands, the form of education is still not optimistic enough. At present, there is still a lack of teaching resources needed by teachers and students, and the market is a mixed market of teaching materials, selling tutorial materials and resources that are highly misleading and of poor quality for normal teaching and learning[1]. Teaching resources are of great importance to the development of English teaching and learning, more in line with learners' actual needs knowledge can make them more interested, more active in learning and easier to improve their English practical skills. While boring, old and tedious teaching resources, teachers' lectures are limited to the knowledge in the textbook without effective expansion and extension, integration of knowledge and innovation, which tend to make students' interest in English gradually decrease and have adverse consequences on their future English learning.

\subsection{Unbalanced teacher-student ratio}

In recent years, due to the expansion of universities, the number of students has increased rapidly, but the corresponding matching team of teachers has not been established, leading to the problem of teacher-student ratio imbalance in many schools, and English teachers are unable to meet the actual teaching needs. However, this is contrary to the basic rules of English teaching and learning, because language learning mainly relies on timely communication and exchange between teachers and students, so that language knowledge can be transferred quickly and effectively, and it is difficult to carry out various forms of language activities in a large class, and it is impossible for teachers to interact with

\footnotetext{
* Corresponding author: nmbaoxiaoli@163.com
} 
each student one by one. This makes the quality of English teaching much lower. In addition, less English application practice will make students' motivation to learn frustrated day by day, and they may even lose interest and initiative in learning English in the long run.

\section{Related data collection and collation}

\subsection{University student data}

College students are the direct targets of college English learning, and their individual qualities determine the quality and effectiveness of English teaching. English education has undergone decades of reforms. Among them, enhancing students' listening and speaking skills, establishing a modern teaching model based on informatization, and cultivating students' active learning capabilities have always been the most important. However, a large number of students are still at a loss in English learning, their learning styles are messy, and their learning results are poor. The Aurora data collected in this article are as follows:

English learning methods for college students

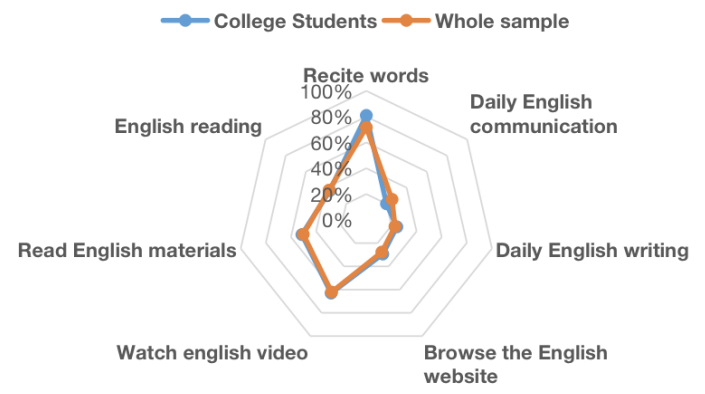

Figure 1. Radar chart of college students' English learning styles

Of course, some students have made detailed learning plans and goals for English learning, but most of these goals are exam-oriented, among which Level 4 and 6 exams are the main ones. They spend a lot of energy and time to memorize words and do all kinds of practice questions, and hardly read study materials that are not related to exams, lacking the ability to apply English in practice. At the same time, few students go to the Internet to obtain English knowledge with rich and colorful contents, and their awareness of learning initiative is not strong enough, and they rely too much on teachers and textbooks for English learning[2].

\subsection{Data on the number of English speakers}

China's economy has undergone radical changes in recent years and has developed rapidly in all aspects. However, there is no doubt that China is still lagging behind in many technical aspects compared with the advanced Western countries. To obtain greater progress in a short period of time, we cannot just rely on ourselves to conduct research, but more to learn the advanced technology of western countries, and mastering the world's common language - English, is a necessary prerequisite[3]. English is everywhere in our lives, we can hear the spread of the English language and communication anytime and anywhere, it has directly affected our lives, for us has become an indispensable part of today's Internet information society, it does not just represent a language, but also a kind of communication link between countries, recognize the importance of learning English, can make us understand more It is important to know the importance of learning English so that we can understand it better and love it more. However, at present, English education in China is at the downstream of the international level.

\section{Related suggestions}

\subsection{Establishing a central educational concept with the help of information technology}

The development and application of information technology has promoted comprehensive changes in education in terms of purpose, content, method and form, and teacher-led and student-led education is more profoundly reflected in the context of educational informatization. With the continuous development and progress of Internet information technology, teachers should fully realize the significant influence of education informatization on education and teaching, establish a student-centered education concept, adjust teaching contents and improve teaching methods in combination with the specific conditions of the Internet era, highlight the role of student autonomy in the teaching process, and provide conditions and guarantee for students to learn translation knowledge in depth. For example, when teaching translation, the previous teaching mode usually consists of oral explanation by teachers, supplemented by boards to facilitate students' recognition, understanding and memory, which makes it difficult for students to make large-scale comparative studies of different translated texts and to master translation research contents. With the technical support of the Internet, teachers can not only use multimedia devices to visually display translation-related knowledge, but also facilitate students to collect a large number of English translation materials, compare and analyze the similarities and differences, advantages and disadvantages of different translation methods with multiple translation texts, and deepen their knowledge of English translation[4].

\subsection{Create an interactive eco-classroom to enhance student-teacher communication}

At the present stage, the English teaching ecological mode in most colleges and universities in China lacks communication between teachers and students in practice. Teachers tend to pay too much attention to their own teaching tasks in the teaching process, ignoring the actual acceptance of students, and most students do not actively ask teachers when they encounter problems, resulting in teachers simply explaining knowledge in English teaching, and the classroom atmosphere is very 
dull. However, English itself is a language, and teachers and students should pay more attention to communication in the process of teaching and learning. From the perspective of ecology, the ecological classroom of college English teaching is a process in which teachers, the environment and other aspects influence each other[5]. Teachers and students need to create an interactive ecological classroom and communicate in a good classroom atmosphere, so as to realize the ecological mode of English teaching and guide the development of the teaching ecosystem. First, the creation of an interactive ecological classroom in the context of "Internet + " education requires teachers to use multimedia facilities and the specific contents of relevant teaching materials to build a natural physical environment for multi-dimensional interaction before teaching specific courses, so as to prepare for the promotion of teacher-student communication. Second, teachers should pay attention to the creation of classroom atmosphere during classroom teaching, and can make more use of Internet technology to play videos and audios related to the course. For example, teachers can play English songs related to the teaching topic three minutes before class to create a harmonious teaching context and bring students into learning. In addition, teachers should observe students' demeanor in the classroom, answer students' questions when they are confused, and design reasonable question-and-answer sessions to enhance communication between teachers and students. Finally, at the end of the lesson, teachers can have students design a script in groups to apply the key grammar in the teaching to the characters' dialogues. During the design process, the teacher can provide appropriate guidance to help students solve problems and improve students' recognition of the teacher, thus promoting the harmonious development of the teacherstudent relationship.

\subsection{Strengthen methodological guidance and cultivate students' independent learning ability}

Compared with traditional teaching, students have wider access to knowledge and less reliance on teachers in the Internet era. It is more beneficial to students' own development and educational reform to teach learning methods and improve students' independent learning ability than to teach knowledge directly. Teachers can cultivate students' independent learning ability in the following directions: firstly, they can teach the method of data orientation and retrieval, so that students can extract the needed information from complex knowledge materials and have the basic ability to solve problems by themselves; secondly, they can make students develop the habit of using English tools and be able to solve words they do not know or understand in the process of reading and translation; thirdly, they can build up students' self-confidence, so that they can learn to think independently, have the active learning attitude, and determine the learning goal of translation independently. attitude, the ability to determine translation learning goals independently and the basic English translation learning methods, etc. Informationization of education is an inevitable trend of education development and reform. With the support of Internet information technology, teachers can improve the translation effect and promote the innovation of informatization teaching by emphasizing the main position of students' learning, combining various teaching modes and cultivating independent learning ability.

\subsection{Rationalize the relationship between the Internet, teachers and students}

In the context of "Internet + " education, the internal structure of the university English teaching ecosystem may be unbalanced to a certain extent. Some teachers do not properly deal with the relationship between connected technology, teachers and students in the classroom, and only repeat the content presented by multimedia devices during the lectures. In addition, some students have an over-reliance on the Internet, believing that online learning can be done anytime and anywhere, which leads to their low motivation to learn in class. Therefore, teachers need to use the Internet wisely when teaching college English and deal with the relationship between the various parts of the ecosystem. Teachers should recognize that Internet technology is only an aid to teaching and learning, and that teachers themselves are the transmitters of knowledge. Teachers should respect the subject position of students and coordinate the relationship between students, language, and environment[6]. Teachers can add more English knowledge to students when they use multimedia devices for teaching. For example, teachers can expand the usage of English words and fixed collocations appropriately.

\section{Future outlook}

\subsection{Long-term and step-by-step attempts to expand influence}

At this stage, in college English teaching, most teachers still have to focus on test-oriented teaching methods. This is due to the limitations of test-taking requirements and cannot be changed in the short term, but we can try gradually. When the task of English teaching is not stressful, Appropriately or even as much as possible to increase students' active learning, active participation, and active design opportunities, enrich the forms of English learning, and gradually transform the burden of learning English into the joy of learning and using English, so that students can truly realize it. Mainly, the desire to "learn by playing", on the one hand, improves the quality of English learning, on the other hand, discovers students' language learning potential, increases their interest in language learning, and truly applies what they have learned in English. Avoid the English learning dilemma of "hard study for more than ten years, once you enter the society, you will be fully refunded". In the field of college English teaching, there is still a long way to go to expand the influence of "Internet+", and we 
need to find the most suitable way and method for college English learning together.

In the future, the Internet will completely break the closed school system, and schools will become a "Taobao platform" that brings together high-quality educational resources. As an open organizational system, schools can use information technology to tap into all the favorable educational resources of the external community, form positive interactions with communities and families, and build an open and diversified schooling pattern. Students can learn in classrooms, communities, science and technology museums and enterprises, or even travel to different cities, depending on the curriculum. The main office of the school is more about providing a learning environment, mentors for growth and a unique school-based curriculum.

\subsection{Change teaching concepts and give full play to subjective initiative}

The arrival of the "Internet + " era has provided an important impetus for the reform of college English teaching. Educators should promptly change teaching concepts, innovate teaching methods, actively build interactive ecological classrooms, continuously improve their own information processing capabilities and English professional capabilities, fully respect and give play to students' subjective initiative, establish a harmonious teacher-student relationship, and build a balanced English The ecological model of teaching can continuously improve the quality of college English teaching and promote the overall and coordinated development of students.

In the future, the independent teacher group will rise, a large number of "skilled", adventurous spirit, good at using the Internet means of teaching excellent teachers will come out of public schools to personalized teaching to expand the supply of education, to promote the transformation and upgrading of online education and the entire education industry. At the same time, the future of the school will be more open, through the combination of online and offline, using the $\mathrm{O} 2 \mathrm{O}$ model to run the school, so that students out of the classroom, into the community, to enjoy the community's excellent educational resources.

\section{Conclusions}

For "Internet + education" to be successful, it cannot remain a patchwork of traditional education models, but rather promote the reengineering of education processes with the support of information technology, transform schools with Internet thinking, and explore new ways of supplying education services. Today, the Internet has revolutionized people's social lifestyles, and behind it lies a new development philosophy and practice paradigm, which is no longer a mere technical means, but a new way of thinking. The so-called "Internet thinking" is a new way of thinking in the Internet era, with six characteristics: cross-border integration, open platform, user first, free as king, experience as core, and big data application. Therefore, "Internet+Education" is not online education, but a change of mindset, which is to use the Internet as the infrastructure and innovative elements to innovate the organization mode, service mode and teaching mode of education, and then build a new education ecosystem in the digital era.

\section{Acknowledgments}

This work was supported by the following projects:

- "Practical Research on English Listening Teaching Model of MOOC + SPOC + Flipped Classroom (YB20200034)".

- "Study on the Ways of Cultivating English Key Competencies of College Minority students (NGJGH2019080)".

- "Study on foreign language learning motivation and Teaching optimization of Mongolian teaching students in ethnic areas(2020JDMY09)".

- "The fourth (JGH2017088), fifth (JGH2018070), sixth (JGH2019054), seventh (JGH2019012), eighth (JGH2020001), ninth (JGH2021005) blended teaching reform of Inner Mongolia University for Nationalities".

- “Analysis of English Majors' Pragmatic Failure and Countermeasures from the Perspective of Intercultural Communication (NMDYB19007)".

\section{References}

1. Wang J. (2021) Analysis of the ecological model of university English teaching in the context of "Internet+" education . English Square, 4: 97-99.

2. Zou H. (2021) Cultural integration and the transformation of university English teaching--A review of "Exploring the transformation of university English education under multicultural integration". Contemporary Education Science, 1: 2.

3. Yang, L. (2021) Research on Teaching English as a Foreign Language in the Context of the Internet: A Review of the Innovative Exploration of College English Teaching in the Perspective of Internet+ [J]. China Science and Technology Paper, 16: 135.

4. Li Z. (2021) The design of hybrid teaching of college English under the background of "Internet+". Modern vocational education, 14: 36-37.

5. Ke W. (2021) The practice and reflection of online teaching of college English during the prevention and control of the new crown pneumonia epidemic. Science and education literature, 3: 174-175.

6. Ruan X. (2021) Research on the construction strategy of efficient college English classroom in the era of "Internet+". Journal of Beijing Printing Institute, 29: 121-123+127. 